\section{David Archer}

is a research officer in the School of Leisure, Sport and Tourism at the University of Technology, Sydney. He is currently involved in a research project that is developing a visitor satisfaction monitoring framework for NSW NPWS. He has authored or coauthored a number of journal and conference papers in the fields of leisure and tourism.

\section{Dr Stephen Wearing} is a senior lecturer in the School of Leisure, Sport and Tourism at the University of Technology, Sydney. He lectures worldwide and has authored or co-authored seven books and over 80 journal and conference papers in the fields of leisure and tourism.

\section{Keywords:}

interpretation, marketing, park management, national parks, Australia
David Archer

Research Officer, University of Technology, Sydney

School of Leisure, Sport

and Tourism, PO Box 222

Lindfield NSW 2070, Australia.

Tel: +61 295145145

Fax: +61295145195

E-mail: david.archer@uts.edu.au

\section{Interpretation and marketing as management tools in national parks: Insights from Australia}

\author{
David Archer and Stephen Wearing \\ Received (in revised form): 8 November 2001
}

\begin{abstract}
Like many public sector organisations in Australia, national parks agencies not only have a role to play in delivering a range of quality services to park users, but also have a mandate to carry out a broader community-building role as well. Today, more than ever, the objectives of national parks agencies reflect their many and diverse constituencies, each with conflicting needs and agendas. This paper examines a management approach incorporating interpretation and marketing tools that will assist in furthering the delivery of park management objectives.

The paper examines the role of both marketing and interpretation as management tools and explores some of the operational and conceptual differences between them. It is suggested that interpretation and marketing can provide park agencies with the ability to manage park users, whether on site or off site, as well as to establish and build relationships with non-park users and the wider community, and can therefore offer a proactive and valuable approach to meeting core objectives. Although mindful of key differences that exist, it is suggested that both tools can be integrated within a synergistic partnership that holds much promise and has an important role to play in the management of national parks generally, and the management of visitors to national parks specifically.
\end{abstract}

\section{INTRODUCTION}

This paper arises from a recognition that tension exists between the alternative uses by Australian national parks agencies of interpretation and marketing as management tools. Although evolving from significant conceptual differences, this tension has primarily emerged as a result of historically conflicting management ideologies. On the one hand, interpretative programmes have long been established and accepted within park management agencies. Park managers have recognised their value as an effective tool in educating and informing park users on the values and features of specific settings and enhancing visitor satisfaction for a number of decades.

In contrast, marketing as a management concept has a relatively 
Proactive tools

\section{Multiple roles of public agencies}

recent and short history within Australian park management agencies. Marketing has usually been viewed with suspicion and misunderstanding by park agencies with little or no expertise in marketing practices. ${ }^{1}$ That said, marketing is now beginning to establish itself as a valued concept for managing national parks, typified by recent planning documents which reflect the desire to redress current management approaches and also acknowledge the role of marketing. ${ }^{2}$ Adding to the tension is the trend among some park management agencies now to subsume interpretative programmes within marketing management frameworks. ${ }^{3}$

The tension between interpretation and marketing as management tools is in the authors' view counterproductive and unnecessary. As it is, park managers face increasing challenges and difficulties in managing the complex interactions between national park users and the physical environment. Rather than continuing to address the symptoms (on-site impacts) of visitor use, a central aim of park managers instead should be to broaden their focus and efforts to address the causes (visitor behaviour, knowledge, awareness and attitudes) of visitor use impacts. Interpretation and marketing offer park managers two effective and proactive (rather than reactive) techniques that can address such causes.

The paper first revisits the role of Australian national parks agencies in order to establish the context in which to examine the use of interpretation and marketing as management techniques. The authors discuss some of the key features of each concept and provide an analysis of operational and conceptual differences between them. In spite of these differences, the authors identify some fundamental commonalities between interpretation and marketing and suggest that an integrated, synergistic framework encompassing the two concepts is required. It is argued that such a framework presents park managers with an effective and more sustainable approach to meeting their many responsibilities and objectives.

\section{THE ROLE OF PARK MANAGEMENT AGENCIES IN AUSTRALIA}

Most public sector organisations differ from private enterprise in that, unlike the private sector, they tend to have multiple purposes. Public sector organisations engage not only in the direct delivery of services to the public, but many also have additional, different purposes $;{ }^{4}$ these additional purposes include building community pride, a community governing itself, promoting choice and building diversity and channels for learning. The complexities facing park management agencies are considerable given the diverse range of stakeholders to be considered, including not only park users, but future users, non-users, commercial sector partners, local communities, citizens, management, employees and other public sector agencies.

This situation is further complicated by the fact that national parks and wilderness reserves in Australia are managed not by a 


\section{Community values}

\section{Management pressures}

single federal agency, but are the responsibility of individual state and territory governments. It is beyond the scope of this paper to examine the responsibilities of each state/territory park management agency; suffice to say that all agencies have common responsibilities and mandates in relation to the preservation and management of their estates.

An increasingly primary focus among Australian park management agencies has been on delivering quality services to the public. This service delivery role typically includes, but is not restricted to, the protection of natural and cultural values, provision of quality recreation and tourism opportunities, interpretation and educational services, weed and feral animal eradication and fire management.

Park management agencies also have an important role to play in building broader community awareness and facilitating a sense of community value, ownership and affinity with national parks. The protection and conservation of Australia's natural and cultural heritage in the long term depends not just on addressing the needs of park users, but also on building a level of community understanding and acceptance of the history, place and value of national parks as representative examples of natural and cultural diversity.

Meeting these responsibilities is increasingly difficult as significant management and external challenges are faced by national parks agencies in Australia. For example, some authors 5,6 have commented on the increasing pressure faced by public sector agencies through the trend to smaller government departments resulting from reductions in public funding, calls for improvement in the quality of services delivered and pressure to outsource the delivery of some services.

At the same time, park managers have come under increasing pressure to accommodate more visitors to their estates. The general reduction in public funding has pressured park management agencies to seek alternative sources of revenue, and has led to a situation where visitor numbers are now a central component of agency performance measurement. Additional pressure has also come from the private sector, with the tourism industry calling for the provision of more opportunities to meet the increasing demands of international and domestic tourists. ${ }^{7}$ National parks and the natural environment are now strategically positioned in planning documents and marketed aggressively by the tourism industry and marketing organisations in all Australian states and territories. This in turn is placing pressure on park management agencies to provide visitors with quality services.

Visitor satisfaction is also used by park management agencies as a key indicator of management performance in delivering quality services and programmes. Ensuring that park users are satisfied encompasses more than just providing settings and facilities. People bring with them various expectations, experiences, needs and 


\section{Recognising other stakeholders}

\section{Changing interpretation techniques}

motivations for visiting a national park. Likewise, their own personal values and attitudes to national parks also play a key role in their level of satisfaction.

In an evolutionary sense, it is possible that the continued delivery by park managers of quality park experiences may bring about a change in visitor and wider community attitudes towards the natural environment. ${ }^{8}$ There is some evidence to suggest that when visitors to national parks obtain a satisfying experience, they will often come closer to supporting the underlying philosophy of park management. ${ }^{9}$

Focusing too much on the consumer or visitor to national parks as the main stakeholder runs the risk of ignoring the important 'community-building' role of most public sector organisations. ${ }^{10}$ If park agencies are to meet their service delivery and communitybuilding responsibilities, it is essential that they provide quality services, promote appropriate visitor behaviour and encourage community awareness, understanding and appreciation of the conservation responsibilities of park agencies, the values inherent in protected areas and opportunities for appropriate visitor use. The remainder of this paper examines how interpretation and marketing might provide park managers with the means of achieving these objectives.

\section{INTERPRETATION AND EDUCATION}

Interpretation is an established and fundamental concept in the management of national parks in Australia. Interpretation is a means for communicating information, stories, values and ideas to assist people in understanding their relationship with the environment. A primary objective of on-site interpretative programmes is the enriching of visitors' experiences by developing their awareness, appreciation and understanding of the range of natural and cultural values inherent in national parks.

Interpretation also allows park managers to educate people on the impacts of visitor use and encourage appropriate behaviour while visiting a national park.

Recent empirical research in Australia has examined whether interpretation does in fact positively influence visitor satisfaction levels and encourage awareness among recipients of their impacts on natural and cultural values. ${ }^{1-13}$ These studies have lent some support to the argument that interpretation is an important antecedent to visitor satisfaction and promotes greater appreciation, learning and awareness of the values inherent in protected areas such as national parks.

Interpretative programmes were originally developed from a scientific perspective and were primarily concerned with providing park visitors with information on important natural and cultural features. ${ }^{14}$ However, the trend to increasing numbers and diversity of visitors, coupled with a general demand for better information, has forced park managers and interpreters to design improved and 
Trend to off-site interpretation

\section{Marketing's commercial origins}

more sophisticated interpretative programmes. Interpretative strategies, that once used only basic signs, now increasingly encompass other communication media such as visitor centres, exhibits, interpretative trails, publications, school education initiatives and ranger-guided programmes.

There has been a shift away from interpretation as solely being an on-site management and education technique. Traditional interpretative programmes delivered to visitors while on site are increasingly being augmented by off-site interpretative strategies that reach not only regular park users, but also communicate with infrequent and non-park users. Off-site interpretation can facilitate communication with these audiences through channels such as tourist information centres, media and publications, the Internet, school education programmes and other community initiatives. Interpretation delivered outside park boundaries permits communication and dialogue with other key stakeholders, and allows the promotion of greater appreciation and awareness of park management agencies and their role across a broader community audience.

In essence, interpretation engages and communicates with people. As a management tool, its effectiveness is strengthened by the development of a sound knowledge of the needs and interests of park users. Just as importantly, effective interpretation also requires an understanding of the needs and interests of infrequent and nonpark users. Targeted interpretative programmes and strategies can then be designed and delivered that are most likely to result in raising the awareness, appreciation and enjoyment of national parks across different stakeholder groups along with the general community.

\section{MARKETING AND PARK MANAGEMENT}

In contrast to interpretation, marketing as a management concept has its origins in the commercial or private sector. Essentially, marketing is concerned with the supply of and demand for goods and services. In its purest commercial sense, marketing is defined as a management component 'designed to plan, price, promote and distribute want-satisfying products, services and ideas for the benefit of the target market and to achieve an organisation's objectives'. ${ }^{15}$ The traditional marketing concept therefore seeks to stimulate and expand consumer demand for products and services. Marketing has also evolved from this traditional model to incorporate alternative marketing approaches. During the last three decades, the marketing concept has evolved in the commercial sector to include the concepts of demarketing, relationship marketing, social marketing and ecological marketing.

In Australia, marketing has a relatively short history within the public sector, including park management agencies. There is a perception among some within park management that the larger interests of the community and environment are at risk of being 
Increasing use of marketing

The role of marketing overwhelmed by market-place and commercial interests associated with the commercial sector. Furthermore, marketing expertise within Australian park management agencies at the planning and policy levels has been either non-existent or sparingly applied, and political and resource realities have also been factors in the reluctance to subsume marketing strategies within park management. ${ }^{16}$ These concerns and issues, while in some respects understandable, need to be addressed.

It is only in recent times that marketing has begun to establish itself as a valued concept in the management of protected areas. ${ }^{17}$ Recent planning documents of some Australian park agencies, for example, have reflected a desire to redress current management approaches and to incorporate marketing programmes and strategies. ${ }^{18}$

A number of factors have led to the increasing use of marketing by Australian park management agencies. Mindful of their increased accountability and obligations to meet performance criteria, including high visitor satisfaction and increased visitor numbers, park agencies have in recent years taken steps to be more outwardly focused and accurately reflect individual and community needs and expectations. Corporate plans now typically recognise the need to establish a more market-driven strategic approach to developing recreational and tourism opportunities in national parks, develop strategic partnerships with other key stakeholders including commercial tour operators, park neighbours and local communities, and make a more conscious effort to provide clear parameters for the public use of natural resources. This is illustrated clearly by some park agencies, such as Parks Victoria, which now makes reference to 'customers' and 'clients' instead of 'visitors' or 'users'.

Marketing provides park management agencies with a strategic tool for managing national parks. It is a powerful medium for communicating with current and potential visitor markets as well as with the wider community. For example, a key element in managing the use of national parks is managing people's expectations. Any mismatch between the expectations of visitors and their on-site experiences can potentially adversely affect satisfaction levels and result in the visitor leaving with a negative attitude towards parks and their management. Appropriate marketing programmes can influence people's expectations through the delivery of realistic and truthful messages and images to targeted user segments. Similarly, marketing allows park agencies to inform different target markets about various experiences available across a range of park settings. This can also include alternative areas, private or otherwise, outside a particular national park.

Raising awareness among various user groups and the community of the detrimental impacts associated with the use of national parks is possible via well-designed marketing programmes. It can be suggested that such information is particularly persuasive 


\section{Key differences between interpretation and marketing}

\section{Limited social science background}

if delivered to target audiences prior to their visit. Studies have found that visitors often appreciate sites more if they are prepared for what they experience. ${ }^{19}$ In a study on visitors to the Grampians in Victoria, for example, it was found that well-prepared school groups were more sensitive to Aboriginal issues and to all issues of environmental management compared to poorly prepared school groups, which accounted for considerable damage in the area visited. ${ }^{20}$ Private commercial tour operators with access to national parks also have an important role to play in preparing tour participants for their nature-based or ecotourism experience.

\section{INTERPRETATION AND MARKETING: HOW DO THEY DIFFER?}

The discussion of interpretation and marketing described above highlights some of the operational and conceptual differences between the two management concepts. Indeed, it is as a result of these differences that the management 'tension' referred to at the beginning of this paper has occurred. Table 1 presents a simple summary of some of the key differences between interpretation and marketing within the Australian context focused on in this paper.

\section{CONSTRUCTING A WAY FORWARD FOR PARK MANAGEMENT}

This paper has referred to the reluctance on the part of some Australian park agencies to acknowledge the potentially beneficial role that marketing strategies and programmes can have on the management of national parks and park users. Such reluctance can, in part, be explained when viewed in the context of the history of national park management in Australia, and most probably also overseas. Many park managers with considerable experience come from backgrounds grounded in the natural sciences, and have limited knowledge or understanding of the use of social scientific enquiry or market-driven commercial considerations in park management. ${ }^{21}$ This is changing, however, as those with backgrounds in business and the social sciences assume key management and planning positions in Australian park agencies.

There is a place within park management for both concepts to be embraced and used together in improving the quality of services delivered to the public, working with key stakeholders and

\begin{tabular}{ll}
$\begin{array}{l}\text { Table I: Some operational and conceptual differences between interpretation and marketing in Australian national } \\
\text { parks }\end{array}$ & Marketing \\
\hline Interpretation & Has a recent, short history in park management \\
\hline Has a long-established role in park management & $\begin{array}{l}\text { Originated from a consumer philosophy } \\
\text { Usually focused on off-site audiences }\end{array}$ \\
$\begin{array}{l}\text { Originated from an educative philosophy } \\
\text { Generally developed and implemented internally by park }\end{array}$ & $\begin{array}{l}\text { Generally developed and implemented externally by the } \\
\text { private sector }\end{array}$ \\
agencies & $\begin{array}{l}\text { Marketing expertise in park agencies is relatively low } \\
\text { Interpretation expertise in park agencies is high }\end{array}$ \\
$\begin{array}{l}\text { Usually delivered to park users only } \\
\text { Is mainly concerned with education and knowledge }\end{array}$ & $\begin{array}{l}\text { Is mainly concerned with pricing, promoting and } \\
\text { matching different products/services to target audiences }\end{array}$
\end{tabular}




\section{Strategic partnerships}

\section{Establish park marketing principles}

\section{Social research}

encouraging greater levels of awareness and appreciation within the community of the benefits of national parks and other protected areas. Both interpretation and marketing techniques lend themselves readily to the provision, management and promotion of tourism and recreation opportunities, environmental education services and the protection of natural and cultural values inherent in national parks.

The increasing reliance on off-site management techniques by park agencies will play an important role in delivering services and building communities. As they are both off-site management tools, interpretation and marketing should be seen to form a 'tandem vehicle' for achieving this. The success of this approach will, however, rely heavily on establishing strategic partnerships between park agencies and key stakeholders. For example, it may be that park agencies can take a leadership role in collaborating and working with licensed tour operators, the tourism industry and the public on interpretation services and programmes. Park agencies already have expertise and experience in communicating interpretative information, stories and ideas to different audiences.

While it is necessary for park agencies to develop and implement their own marketing services and programmes, they may benefit greatly by utilising the expertise of the private sector in marketing national parks. Indeed, Parks Victoria is an example of an Australian park management agency which has increasingly utilised external marketing organisations to assist in developing marketing programmes and strategies. At the same time, it is preferable for park agencies to work with commercial and public tourism marketing organisations to educate them about the stresses placed on the environment resulting from current or increased-use levels, and to encourage them to incorporate appropriate environmental messages in their own marketing programmes. This requires that park marketing principles are set in relation to ensuring visitor expectations are realistic, images portrayed are relevant and aligned with park management philosophy, and that the broader community have a heightened understanding and awareness of the national park resource.

Feedback from park users and other stakeholders by way of surveys, focus groups and community consultation, along with information on non-park users, is a necessary requirement of both interpretation and marketing. Different audiences have different information needs requiring a range of alternative delivery methods to reach them. Regular social research and visitor monitoring by park managers is critical in keeping management and decision making informed by 'hard evidence' rather than relying solely on instincts or 'gut feelings'.

Both interpretation and marketing should be considered as interdependent management concepts. Interpretation uses a variety of communication methods and is delivered to audiences on site, and increasingly off site as well. Marketing is important in 


\section{Broad community support}

\section{Communication is a vital link}

connecting target audiences with various interpretative services and programmes. Likewise, interpretation provides contextual meaning and promotes a range of themes found in parks that are increasingly marketed to various target audiences.

A national park cannot be effectively managed without the support and backing of its users and the public. It follows that no national park system can adequately fulfil its roles without achieving a dialogue with the public - a failure to undertake such dialogue is likely to alienate some recreational users and decrease the level of public support for parks. This would be a very serious situation, for without public support it is unlikely that there would be such a diverse and extensive range of environments protected. A strong base of public support can only be achieved through adequate marketing and interpretation, and each in a way needs the other. Interpretative techniques and associated actions get messages out to user groups and include both on-site and off-site methods. However, marketing techniques are able to address gaps in current interpretation and target messages more effectively to the public. While marketing is able to raise awareness, it is also essential that the national park provides information that seeks to change behaviour, and interpretation is best able to achieve this. Table 2 shows how interpretation can benefit from the use of marketing.

In essence then, interpretation and marketing share the ability to engage with people. Communication is the fundamental link between the concepts - both are primarily about communicating. For park agencies this means communicating with park users, nonpark users, the tourism industry, recreational groups, marketing bodies, park neighbours, special interest and minority groups, government, other public sector organisations and communities.

The interpretation and marketing functions of park management agencies should be developed and administered not in isolation of one another, but with an understanding of each other's aims and objectives so as to ensure synergies result. By integrating interpretative and marketing strategies and programmes to engage with park users, other key stakeholders and the broader

Table 2: How interpretative objectives can be furthered by marketing techniques

\begin{tabular}{|c|c|}
\hline Interpretation & Marketing \\
\hline $\begin{array}{l}\text { Stimulation of an environmental consciousness and } \\
\text { broad-based conservation ethic }\end{array}$ & $\begin{array}{l}\text { Able to determine most relevant target audiences } \\
\text { through market segment theory }\end{array}$ \\
\hline $\begin{array}{l}\text { Raise awareness of regulations and codes designed to } \\
\text { minimise impacts }\end{array}$ & $\begin{array}{l}\text { Able to package this to the general public via imaging } \\
\text { and theme techniques }\end{array}$ \\
\hline $\begin{array}{l}\text { Stimulation of behavioural change to minimise personal } \\
\text { impacts upon the environment }\end{array}$ & $\begin{array}{l}\text { Presents this through market attitude research as more } \\
\text { relevant ideas for people to adopt }\end{array}$ \\
\hline Support for national parks & $\begin{array}{l}\text { Able to gauge the receptivity of the general public to } \\
\text { these ideas through market surveys }\end{array}$ \\
\hline Usually delivered to park users only & $\begin{array}{l}\text { Because its approaches are based on marketing } \\
\text { principles it is able to reach the general public and as } \\
\text { such can deliver to both park users and non-park users }\end{array}$ \\
\hline
\end{tabular}


Need for integration and synergies community, park agencies can increase the likelihood that they will meet their service delivery and community-building responsibilities.

\section{CONCLUSION}

This paper has sought to highlight the underlying tension which exists in some Australian park agencies in the use of interpretation and marketing as park management tools. Such tension is generally the product of conflicting management ideologies between the 'old school' versus the 'new school' of management thought. Discussion on the comparative origins, objectives and features of both techniques has developed within the context of the dual roles of park agencies as service deliverers and community builders.

This paper suggests that while the emphasis on users of national parks is important, interpretative and marketing programmes should also encompass the range of stakeholders along with the broader community. It is recognised that both management techniques aim to engage with people through communication, and are easily adaptable to off-site applications as well as on site. Indeed, it is the applicability of interpretation and marketing tools to off-site management objectives that provides significant advantages over traditional site-based management options.

Although they each take a different path towards meeting common park management objectives in a conceptual sense, the integration and partnering of interpretation and marketing in the planning, development and delivery stages of management are both achievable and necessary. In future, those park agencies that recognise this will be in the best position to meet their service delivery objectives, encourage community involvement in conservation management and promote community solutions to park management challenges.

\section{References}

1. Wearing, S. and Archer, D. (2001) 'Towards a framework for sustainable marketing of protected areas', Australian Parks and Leisure, Vol. 4, No. 1, pp. 33-49.

2. NSW NPWS (1997) Draft Nature Tourism Strategy, Sydney, NSW National Parks and Wildlife Service.

3. Nelson, H. and Wearing, S. (2000) 'Namadgi District Interpretation Strategy and Action Plan', Report to ACT Forests and ACT Parks and Conservation Service, Canberra.

4. Donnelly, M. (1999) 'Making the difference: Quality strategy in the public sector', paper presented at the Third International and Sixth National Research Conference on Quality Management, Melbourne, RMIT University Centre for Management Quality Research.

5. Coaldrake, P. and Stedman, L. (1998) On the Brink: Australian Universities Confronting their Future, St Lucia, University of Queensland Press.

6. Foster, D. (2000) 'Addressing quality issues in a public sector context: Management in national parks', paper presented at the Fourth International and Seventh National Research Conference on Quality Management, Sydney.

7. Ibid.

8. Forestell, P. (1990) 'Marine education and ocean tourism: Replacing parasitism with symbiosis', in Miller, M.I. and Auyong, J. (Eds) Proceedings of the 1990 Congress on Coastal and Marine Tourism - A Symposium and Workshop on Balancing Conservation 
and Economic Development, National Coastal Resources Research and Development Institute, Newport, OR.

9. McArthur, S. (1994) 'Acknowledging a symbiotic relationship — Better heritage management via better visitor management', Australian Parks and Recreation, Vol. 30, No. 3, pp. 12-17.

10. Foster, ref. 6 above.

11. Pearce, P. and Moscardo, G. (1998) 'The role of interpretation in influencing visitor satisfaction: A rainforest case study', paper presented at the Eighth Australian Tourism and Hospitality Research Conference, Gold Coast, February.

12. Woods, B., Moscardo, G. and Pearce, P. (1997) 'Interpretation and tourism: The Skyrail experience', paper presented at the Cooperative Research Centre for Tropical Rainforest Ecology and Management Annual Meeting, Cairns, 11-13 June.

13. Woods, B. and Moscardo, G. (1996) 'Adding value to tourist operations through interpretation: Is interpretation good for tourism or tourism good for interpretation?', paper presented at the Interpretation Association Australia Conference, Bendigo.

14. Wearing, S. and Neil, J. (1999) Ecotourism: Impacts, Potential and Possibilities, Butterworth-Heinemann, Oxford.

15. Stanton, W., Miller, K. and Layton, R. (1992) Fundamentals of Marketing McGrawHill, Sydney.

16. Wearing and Archer, ref. 1 above.

17. Wearing, S. and Bowden, I. (1999) 'Tourism and a changing public sector culture for parks', Australian Parks and Leisure, Vol. 1, No. 3, pp. 6-8.

18. NSW NPWS, ref. 2 above.

19. Gale, F. and Jacobs, J. (1987) Tourists and the National Estate, Special Australian Heritage Publication Series No. 6, Australian Heritage Commission, Canberra.

20. Ibid.

21. Wearing, S. and Brock, M. (1991) 'National parks and tourism: An attitudinal study of managers in national parks', Australian Parks and Recreation, Vol. 27, No. 1, pp. 29-35. 